\title{
Callicott's Holism: \\ A Clue for a Classical Realist Contribution to the Debate Over the Value of Animals
}

\author{
Richard J. Klonoski \\ University of Scranton
}

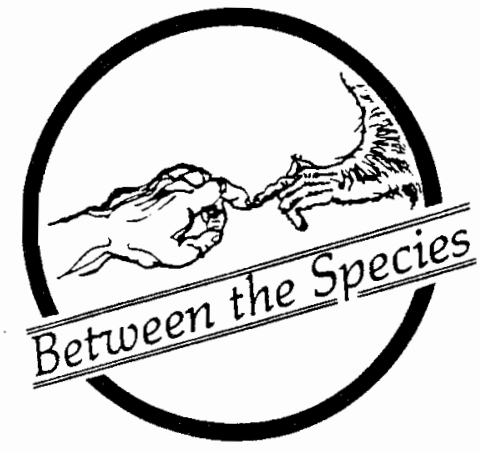

help orient classical realists in their efforts to contribute to the discussion about ethics and animals.

The essay to which I am referring is "Animal Liberation: A Triangular Affair." The title betrays the primary purpose of the piece. Callicott argues that the debate over the liberation and rights of animals is not a bipolar one, as has often been maintained, but is, rather, three-sided. The three competing positions are, as Callicott distinguishes them, ethical or moral humanism, humane moralism, and environmental ethics. The ethical humanists argue that nonhuman animals are not worthy of being accorded moral standing because "Only human beings are rational, or capable of having interests, or possess 'self'-awareness, or have linguistic abilities or can represent the future...."2 This does not necessarily mean that animals may be treated inhumanely. Rather, animals may be treated as "means" and need not be treated as persons or ends in themselves.

The humane moralists, on the other hand, argue against the ethical or moral humanists, claiming that even in lieu of possessing the aforesaid qualities that serve to constitute personhood, animals are "sentient" beings. Since animals possess "sensibility," it is argued that they suffer pain and that "...we are morally obliged to consider their suffering as much an evil to be minimized by conscientious moral agents as human suffering."3

While the ethical humanists and the humane moralists surely differ as to whether animals are beings who can

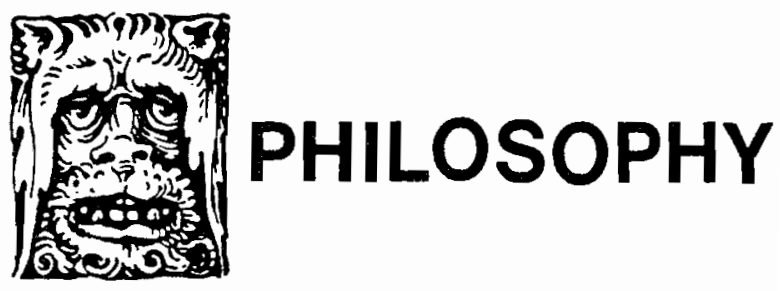


legitimately have moral consideration extended to them, Callicott argues that they are similar in important ways. He argues that adherents to both of these theoretical approaches locate moral value in "individuals" (whether human or human and animal). Both approaches extend moral consideration to some individuals and exclude others. In the end Callicott argues that both positions are atomistic, reductive, and distributive.

As distinguished from ethical humanism and humane moralism, Callicott defines environmental ethics as a "holistic or collective," and therefore not atomistic or reductive, theoretical approach to the valuation of animals. Indeed, this environmental ethic is called "ethical holism" because it "...locates ultimate value in the [whole] "biotic community'..." It is in fact the greatest good, i.e., the summum bonum, of the whole ecosystem, or the natural community, which "...serves as a standard for the assessment of the relative value and relative ordering of its constitutive parts and therefore provides a means for adjudicating the often mutally contradictory demands of the parts considered separately for 'equal' consideration."

Animals, as only one of the constitutive groups which make up the biotic community, would have their value determined, like the other parts, relative to the practical impact that such a valuation would have on the other natural entities (e.g., plants, minerals, waters, soils, etc.). More importantly, the value accorded to animals would be assigned in light of the projected effect on the "common good" or the "...integrity, stability, and beauty of the biotic community..." Callicott's environmental ethic is "holistic" and not reductive because it does not arise out of a reduction to some privileged individual(s) which serves as the standard for moral consideration. Rather, moral consideration is born of a comprehensive valuation of the biotic community as such.

Callicott's inspiration for this holistic environmental ethic is, of course, Aldo Leopold and his "land ethic." In fact he argues that Leopold's land ethic is a modern classic and can be treated as "the standard example, the paradigm case... of what an environmental ethic is." 7 He suggests that while he will employ Leopold's land ethic as something of an exemplar type in his effort clearly to distinguish environmental ethics from animal liberation and animal rights-based ethical theories, he does not hold that all environmental ethical systems must conform to Leopold's to be termed "environmental ethics."
On his way to the claim that "holism" is the most "creative, interesting and practical" theory among the three in question, Callicott gives a brief but very nice summary of Leopold's land ethic. There is one especially noteworthy moment in this summary and analysis of Leopold's ethic. It is the point at which Callicott attempts to explicate the core of the land ethic by comparing it to Plato's moral and social philosophy. It is in this comparison that we can discern a "clue" as to the direction that classical realist approaches to the valuation of animals might take. His suggestion is that Plato's ethic is holistic in a very similar way to that holism that lies at the heart of Leopold's land ethic.

Callicott's comparison of Plato's position to that of Leopold is captured in the following passage:

From the ecological perspective, according to Leopold as I have pointed out, land is like an organic body or like a human society. According to Plato, body, soul and society have similar structures and corresponding virtues. The goodness of each is a function of its structure or organization and the relative value of the parts or constituents of each is calculated according to the contribution made to the integrity, stability and beauty of each whole. ${ }^{8}$

Callicott goes on to exploit this notion that the order and goodness of the whole is the standard for the function and the value of the parts. He cites several examples of how this principle was employed in Plato's Republic.

The good of the ideal state, indeed the possibility of justice and happiness in that state, depended on the assignment of function and value in all arts and sciences, in virtually all human ambition, in such a way that the well-being of the community or the city as a whole was preserved. Of course, in the Republic the discussion of the just, well-ordered city occurs first, in part, to make way for the claim that a soul is comparable to a city and, as equally well-ordered, would be both just and happy. The parts of the soul, i.e., reason, spirit, and desire, having different functions and capacities for excellence or virtue, needed to be ordered in such a way that there occurred a harmony. This harmony was understood as the primary condition necessary for a morally virtuous life. This balance, stability, and beauty of the order of soul and city, Callicott suggests, is nicely mirrored in Leopold's land ethic. 
But Callicott does not plumb the comparison of Leopold and Plato nearly enough. First, scholarship on the Republic has shown that "lifting" Plato's political philosophy, for example, out of this dialogue is a difficult enterprise at best. 9 Second, and more importantly, the comparison between Plato and Leopold remains at the surface. He invokes Plato's ethics and politics, and even in the examples of the subordination of parts to whole that he cites from the Republic, Callicott doesn't appreciate the support for these claims he might have gotten by unearthing the metaphysical and ontological foundations of Plato's political philosophy and value theory. ${ }^{10}$ It is with a fuller appreciation of these metaphysical underpinnings that classical realists will begin to discern a true compatibility between holistic environmental ethical systems like those of Leopold and Callicott and systematic, metaphysical classical realist philosophies, like that of Plato.

In the remainder of this essay I'll try to make this last claim more clear and compelling. However, I would like to place the same qualification on my remarks about the use of Plato's thoughts that Callicott places on his, at the beginning of the essay, "Animal Liberation: A Triangular Affair," regarding his discussion of Leopold. Recall, Callicott said that while "Aldo Leopold...is universally recognized as the father or founding genius of recent environmental ethics," ${ }^{11}$ he only intended to use Leopold's land ethic as a "paradigm" or the exemplary type of the holistic environmental ethic he was about to describe.

It seems to me that Plato has been viewed as something of a "father" or founding genius of classical realism. ${ }^{12}$ And yet I am making no claim that all classical realist forays into the battle over the value of animals need be Platonic. I am claiming only that perhaps by using Plato's philosophy as an exemplar of classical realism we can find a uniquely classical realist way into the debate about ethics and animals.

Let me return now to my earlier claim that Callicott, while leaving a clue for classical realists, perhaps didn't exploit his comparison between Leopold and Plato enough. ${ }^{13}$ Callicott says that "Plato...never develops anything faintly resembling an environmental ethic. Plato never reached an ecological view of living nature." 14 He follows this remark with the claim that Plato was primarily, “....if not exclusively, concerned with moral problems involving individual human beings in a political context..."15 It seems to me that the first of these remarks by Callicott is overstated and the second is quite wrong.
While it is perhaps true that we don't have a dialogue or even a body of texts which bear out a Platonic environmental ethic, there are numbers of places, most especially in the Republic, the dialogue to which Callicott refers most, where interesting connections can be made between some of the key notions in Callicott's holistic environmental ethics and Plato's philosophy. A brief discussion of just some of these connections will demonstrate both the richness of Callicott's original comparison of Leopold and Plato and his failure to see beneath the social and political level of the comparison to its metaphysical foundation.

At the center of the holism of Callicott and Leopold is the notion that the biotic community has a summum bonum, a common, holistic good. This summum bonum is defined by Callicott, in this essay, in terms of "stability, integrity and beauty." 16 The holistic ecological perspective sees the value of the biotic community as the standard for the value of its members. This good is one which, as stable, beautiful and unified or integral, is of a certain "order." In fact Callicott's discussion of holism is pervaded by the notion that the goal of environmental ethics is to discern the "order" of the biotic community and to assign value and to prescribe legitimate use of the constituents of the community in a way that contributes to the unity, harmony and balance of the eco-system.

As we know, Plato makes similar kinds of claims about the good of souls and cities. Justice is in fact defined several times in the Republic as the harmony or appropriate order among the parts of the whole, whether in cities or in souls. ${ }^{17}$ We must remember, however, that for Plato, especially in the Republic, justice is "natural" to us. In fact, the argument about the origin and nature of justice is framed against a backdrop of claims by some people that being just is "against our nature."18

Justice in the soul is understood by Plato to be "natural" in the same way that the "natural" order of the body is said to be health. So, the natural good, order and excellence of the soul is justice. In relation to city and soul Plato ties together, under the umbrella of justice, goodness, integrity or unity, stability or harmony, and ultimately beauty, as he refers often to the "fine" or beautiful nature of the well-ordered soul.

Yet even more interesting is the fact that Plato uses the word phusis and various forms of it to indicate the nature of things, or what he thinks is "natural." The Greek word phusis itself referred to the natural or 
appropriate order, constitution or structure of a person or thing. ${ }^{19}$ For a thing to have a "nature" was for it to have an appropriate order, an essential arrangement of the parts in the whole.

For Plato the stability, beauty, and integrity of the ideal or excellent soul or virtuous and ideal city, i.e., the appropriate order and good of each, was "natural." Even the universe for him was a kosmos or an "order" and was so "by nature."

While Callicott may have been correct in saying that Plato never developed a systematic environmental ethic, it seems clear that by tying together the idea of the phusis or the nature of things with their inherent "order" or structure, Plato laid the "metaphysical groundwork" for those who would take this clue as foundational to arguments that would maintain that the natural world was to be valued as a unity, an order, a whole.

It must also be mentioned that Callicott is, of course, correct in saying that the body, soul, society and cosmos are the "wholes" of Plato's universe. 20 They are not, however, the only, or perhaps the most important ones. I am thinking about the wholes to beat all wholes, i.e., the transcendent ideas or forms. In Book X of the Republic, we learn that these essences are "in nature" produced by god. They were begotten by god as "one" by nature.

The natural order, and thus reality itself, is constituted by the forms. It is toward this more comprehensive sense of "the natural" as "the orderly" or "the whole" that ecological holisms like those of Leopold and Callicott could turn. The real consists in the orderly. Thus the stability, integrity, and beauty of Callicott's biotic community would be for Plato an imitation of the more cosmic harmony, beauty and unity of the intelligible realm of ideas, of reality itself. ${ }^{21}$

This essay has been an attempt to provide classical realists with one possible avenue by way of which they may contribute to the ethics and animals debate. If Plato's classical realism is taken as an example, it would seem that holistic or environmental ethical approaches to establishing the value of animals, as opposed to the ethical humanist and the humane moralist approaches, would prove most fruitful.

The focus of such holistic approaches on unity, on the good of the whole, and on more ultimate, largely transcendent principles like stability, beauty, and integrity, would be most complemented by classical realist philosophies which were founded on similar ultimate notions which imply an understanding of nature as an order and a unity. The whole idea of approaching ecology 22 in general, and the valuation of animals in particular, from a metaphysical, foundational perspective on the relationship between the whole and its parts, the one and the many, would provide for rich insight and for a unique contribution to the valuation of animals debate.

\section{Notes}

\begin{abstract}
${ }^{1}$ I will be quoting from the version of this essay which appeared in People, Penguins and Plastic Trees: Basic Issues in Environmental Ethics (Belmont, CA: Wadsworth Publishing Company, 1986), pp. 184-203. The essay was originally printed in Environmental Ethics, 2, no. 4, (Winter 1980): pp. 311-338.
\end{abstract}

${ }^{2}$ Ibid., p. 186. It should be mentioned that Callicott expends considerable effort identifying individual theorists with one of the three major positions he defines. $I$, of course, will not be expending efforts in this direction, because the point of this present essay is not to parse and/or categorize theories, but to determine a general theoretical direction which would be suggestive or fruitul for classical realists to follow.

${ }^{3}$ Ibid., p. 187.

${ }^{4}$ Ibid., p. 197.

${ }^{5}$ Ibid., p. 190.

${ }^{6}$ Ibid.

${ }^{7}$ Ibid., p. 184.

${ }^{8}$ Ibid., p. 192.

${ }^{9}$ For instance, it is unclear to what extent, if any, Plato intended the ideal city of the Republic to be an actual "blueprint" for society. More to the point, the examples that Callicott cites concerning infanticide, the mating ritual and the destruction of the family alone need to be interpreted contextually.

${ }^{10}$ Callicott does cite as well Plato's Gorgias, 503d-507a, (p. 202, Note 33). However, the discussion of the relationship of "whole to parts" is again fundamentally ethical or social/ political. A major concern in this Platonic dialogue is, of course, rhetoric.

${ }^{11}$ Callicott, p. 184.

${ }^{12}$ Plato is a classical realist, in part, because he argued for the existence of the "ideas" or the "forms." He claimed that the forms were separate, intelligible beings that existed independently of the mental or linguistic activities of human beings. These forms, e.g., justice, beauty, courage, etc., were considered by him to be the ultimate realities, the ground of all claims to knowledge and truth. 
${ }^{13}$ It must be said that Callicott's project, in his essay, and mine in this present paper are quite different. I am in no way arguing that his "holism" needs a classical realist defense.

${ }^{14}$ Callicott, p. 202 , note 37.

${ }^{15}$ Ibid.

${ }^{16}$ See p. 190 , for example.

${ }^{17}$ See Plato, The Republic of Plato, Allan Bloom. Trans. with notes and Interpretive Essay (New York: Basic Books Inc., 1968): 435b-c and 443a-e.

${ }^{18}$ See the "Story of Gyges," in Republic II, 359b\&ff. One point of this tale is that humans, "by nature," are unjust.

${ }^{19}$ See listing of phusis in Liddell and Scott's Greek English Lexicon (Oxford: Oxford University Press, 1976).
${ }^{20}$ See Callicott, p. 202.

21 See Republic, 596 b-e.

22 Plato so often uses "health" as a metaphorical way of talking about order and nature or what is "natural." (In footnote 25 , p. 201, Callicott notes that toward the end of "The Land Ethic," Leopold himself discusses "land health.") Environmental holists and/or ecologists could be encouraged to "push" such metaphors so as to uncover the metaphysical grounds of their own claims. Callicott is quite right to point out that "Ecology makes it possible to see land... as a unified system of integrally related parts... [as a] whole...." (p. 189). He adds that ecological science can do this "... without the least hint of mysticism or ineffability" (ibid.). However, metaphysics may provide a more all-encompassing conceptual framework from within which to articulate and defend environmental holism and the inherent value of nature and natural entities, including animals.

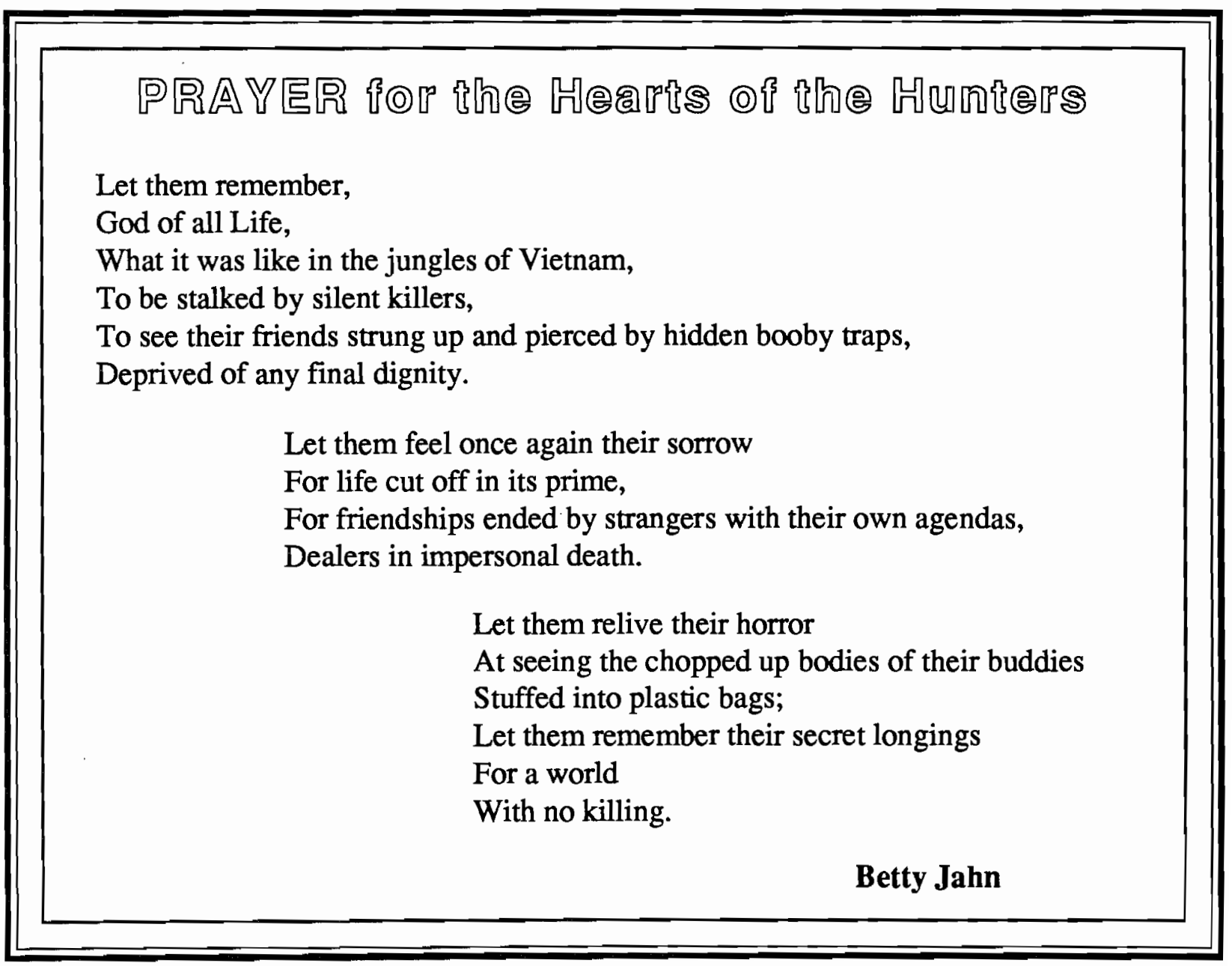

